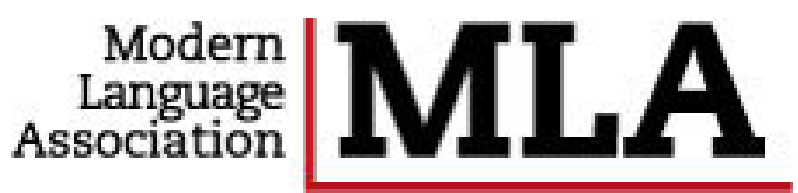

Bertran de Born and Sordello: The Poetry of Politics in Dante's Comedy Author(s): Teodolinda Barolini

Source: PMLA, Vol. 94, No. 3 (May, 1979), pp. 395-405

Published by: Modern Language Association

Stable URL: http://www.jstor.org/stable/461927

Accessed: $01 / 04 / 201311: 23$

Your use of the JSTOR archive indicates your acceptance of the Terms \& Conditions of Use, available at

http://www.jstor.org/page/info/about/policies/terms.jsp

JSTOR is a not-for-profit service that helps scholars, researchers, and students discover, use, and build upon a wide range of content in a trusted digital archive. We use information technology and tools to increase productivity and facilitate new forms of scholarship. For more information about JSTOR, please contact support@jstor.org. 
TEODOLINDA BAROLINI

\section{Bertran de Born and Sordello: The Poetry of Politics in Dante's Comedy}

$\mathrm{T}$ HE STATURE Dante grants Sordello in the Comedy has long puzzled critics, since it seems greater than warranted by the achievements of this Provençal poet. Not only does the meeting with Sordello, in the sixth canto of the Purgatorio, serve as the catalyst for the stirring invective against Italy that concludes the canto, but Sordello is assigned the important task of guiding Vergil and Dante to the valley of the princes and identifying for the two travelers its various royal inhabitants. This seems a large role for a poet who was-and is-best known as the author of a satirical lament with political overtones, the lament for Blacatz. Indeed, although there is a definite consonance between the tone of that lament and the hortatory tone of the character in the Comedy, Sordello's poetic oeuvre does not by itself convincingly account for his function in Dante's poem. In the absence of other explanations, however, critics have traditionally agreed that we must turn to Sordello's planh for an understanding of his position in the Comedy. ${ }^{1}$

In this so-called lament Sordello violently satirizes the princes of Europe, whom he criticizes for their cowardice; in fact, the work is more a sirventes than a planh, more a diatribe against the living than a lament for the dead. The poem begins conventionally enough, bewailing the death of Blacatz and complaining, in the usual manner, that all virtue and bravery have died with him; it soon becomes apparent, however, that this death is more a pretext than a theme. Consequently, Blacatz is not mentioned after the first verse:

Planher vuelh en Blacatz en aquest leugier so, ab cor trist e marrit; et ai en be razo, qu'en luy ai mescabat senhor et amic bo, e quar tug l'ayp valent en sa mort perdut so; tant es mortals lo dans qu'ieu non ai sospeisso que jamais si revenha, s'en aital guiza no; qu'om li traga lo cor e que $\cdot n$ manio $\cdot 1$ baro que vivon descorat, pueys auran de cor pro.

Premiers manje del cor, per so que grans ops l'es l'emperaire de Roma, s'elh vol los Milanes per forsa conquistar...

I want to lament Sir Blacatz in this light melody, with a sad and afflicted heart; and I have good reason, for in him I have lost a lord and a good friend, and because all that is virtuous is lost in his death. This damage is so fatal that I have no hope that it can ever be remedied, if not in this way: let his heart be taken out and the barons eat of it who live without heart - then will they have heart.

Let the first to eat of the heart, because he has great need of it, be the Emperor of Rome, if he wants to conquer the Milanese by force ...2

Using throughout the poem the motif of Blacatz' heart as a necessary source of courage for the cowardly kings, Sordello pillories a different prince in each stanza. By the end he has indicted the emperor, Frederick II, as well as Louis IX of France, Henry III of England, Ferdinand III of Castile and León, James I of Aragon, Thibaut I of Navarre, Raymond VII of Toulouse, and Raymond Bérenger IV of Provence-all for being too weak and spineless to fight for their rightful territories.

The Sordello of Purgatorio vii is also given to judging the behavior of rulers; here, too, he rebukes the princes for negligence and for failing to govern properly, much as he had done in his lament while on earth. There has been a shift, however, from the simple feudal attitude of the planh, in which the loss of land is considered a stain on the personal honor of the prince, to the 
lofty Dantesque concept of the sovereign's moral obligation to his subjects. Once this inevitable transposition has been taken into account, the correspondences between the historical Sordello and the Sordello of the Comedy are clear enough -and yet somehow inadequate, for the discrepancy between the poet's stature as a person and his stature as a character remains. Neither Sordello's poetry nor his Lombard origins (which permit him to greet Vergil with the famous verse "O Mantoano, io son Sordello / de la tua terra!" 'O Mantuan, I am Sordello of your land!') satisfactorily justify his prominence in the Comedy-justify it, that is, in a more than mechanical way. ${ }^{3}$

It is this gap between the real and the fictional that has made Sordello the subject of so much critical debate, to the point of being labeled "l'enigma dantesco" by a scholar who believed that the character would remain a problem until biographical material was discovered to explain Dante's esteem for him. ${ }^{4}$ In this paper, however, I propose a reading for Sordello that requires no external data. I submit that there is an internal coherence to the Sordello episode, that there are internal reasons both for his role and for his stature. A comparison between Sordello and another of the Comedy's poets, Bertran de Born, will, I believe, shed some light on Dante's underlying logic and intentions.

The analogy between Sordello and Bertran de Born is by no means self-evident. Indeed, Thomas Bergin sets up a quite different pattern, claiming that there is a trio of Provençal poets in the Comedy, composed of Bertran in the Inferno, Arnaut Daniel in the Purgatorio, and Folquet de Marselha in the Paradiso. "Of all Dante's triads," he writes, "the Provençal poets are most obviously and architectonically disposed, one for each cantica, each one clearly and prominently placed, varying only, I would say, in their degree of integration with their milieu."5 But Bergin is then left with the problem of a fourth poet who wrote in the langue d'ocSordello-and is forced to conclude that Dante did not intend Sordello "to 'count' as a Provençal figure. . . . Dante sees in Sordello not the Provençal poet but the Italian-born patriot and judge of princes" (p. 25). This interpretation violates one sense of the episode, for Sordello's tribute to Vergil at the beginning of Purgatorio vii is clearly the tribute of one poet to another.

Without denying the validity of Bergin's Provençal trio, I would comment that, although Dante is a poet of symmetries, his symmetries are not necessarily straightforward or clear-cut. In fact, Dante tends to establish contradictory or, rather, counterbalancing symmetrical structures, such as the odd asymmetrical canticle of thirty-four cantos, which then creates a new symmetry by bringing the total number of cantos to one hundred. Similarly, the neat symmetrical relationship between the Comedy's three Provençal poets is marred by the presence of a fourth, Sordello, and again the solution may be overlapping symmetries: the trio pointed to by Bergin and the duo that I am suggesting, which, significantly, includes as its pivotal figure precisely the poet excluded by the first arrangement. My claim that Sordello should be juxtaposed with Bertran de Born, as Cacciaguida is with Brunetto, or Cunizza with Francesca, is based on one simple but, I believe, telling observation: of all the lyric poets in the Comedy only Bertran and Sordello are not love poets. In other words, if we look, not at the restricted group of Provençal poets, but at the larger group of all lyric poets in the Comedy-Bertran de Born, Sordello, Bonagiunta da Lucca, Guido Guinizzelli, Arnaut Daniel, and Folquet de Marselha (in order of appearance) - the first two stand out as poets whose major poetic concerns are different from those of the others; indeed, Bertran and Sordello are revealed as the Comedy's two "political" poets. Surely this identifying bond between them is sufficient basis for comparison. ${ }^{6}$

Before examining these two poets as they are presented in the Comedy, I should like to say a word about the poetry of Bertran de Born. He, too, was celebrated for laments; the two traditionally attributed to him are both for Prince Henry, also called the Young King (because he was crowned during his father's lifetime, since Henry II of England hoped thus to ensure the succession), a prince with whom Bertran was presumably on intimate terms. ${ }^{\top}$ These poems are the famous "Si tuit li dol $\mathrm{e} \cdot \mathrm{lh}$ plor $\mathrm{e} \cdot \mathrm{lh}$ marrimen" and the less well known "Mon chan fenisc ab dol et ab maltraire." It is worth noting that, unlike Sordello's planh for Blacatz, these are true laments. They follow the planh's customary format of both praising the dead man 
and mourning his loss. The first stanza of "Si tuit li dol" is representative of the poem and of the genre:

Si tuit li dol $\mathrm{e} \cdot \mathrm{lh}$ plor $\mathrm{e} \cdot \mathrm{lh}$ marrimen $\mathrm{E}$ las dolors $\mathrm{e} \cdot \mathrm{lh}$ dan $\mathrm{e} \cdot \mathrm{lh}$ chaitivier Qu'om anc auzis en est segle dolen Fossen ensems, sembleran tot leugier Contra la mort del jove rei engles, Don rema pretz e jovens doloros E. 1 mons oscurs e teintz e tenebros, Sems de tot joi, ples de tristor e d'ira.

If all the sorrow, tears, anguish, pain, loss, and misery which man has heard of in this sorrowful life were heaped together, they would all seem light compared to the death of the young English king; for him worth and youth grieve, and the world is dark, covered over, and in shade, lacking all joy, full of sadness and spite.

(Die Lieder, p. 98)

The grief of the poet is echoed formally in the repetition of "marrimen" and "ira" at the end of the first and last lines of each stanza. The Young King ("jove rei engles") is also mentioned in each stanza, indeed always in the same place, at the end of the fifth line, thus constituting with "marrimen" and "ira" the obsessive poles about which the poem moves.

Bertran was also the author of numerous sirventes celebrating war, poems that take delight in describing the carnage of the battlefield in vivid detail:

Ie·us dic que tan no m'a sabor
Manjar ni beure ni dormir
Com a, quan auch cridar: "A lor!"
D'ambas las partz et auch ennir
Chavals vochs per l'ombratge,
Et auch cridar: "Aidatz! Aidatz!"
E vei chazer per los fossatz
Paucs e grans per l'erbatge,
E vei los mortz que pels costatz
An los tronzos ab los cendatz.

I tell you that there is no such savor for me in eating or drinking or sleeping, as when I hear men shouting "At them!" from both sides, and hear the horses neighing in the shadows; and hear men cry "Help! Help!" and see small and great fall in the ditches, on the grass; and when I see the dead, who through their sides have the stumps of lances with silken pennants.

(Die Lieder, p. 93)
In these poems, Bertran constantly urges the barons on to battle, as does Sordello in his lament for Blacatz. Sordello, however, recommends war as an antidote for cowardly behavior, which he finds reprehensible in princes, and as a means of securing lost territory, whereas Bertran's reasons for warmongering are unabashedly mercenary and self-serving, and his only concern is loot. Therefore, even when Bertran and Sordello share similar social themes and a similar polemical bent, Bertran's verse completely lacks the didactic element that distinguishes the poetry of Sordello. Sordello, in his lament for Blacatz, as in his "Ensenhamens d'onor," wants to instruct us in correct chivalric and princely conduct (this is explicit in the title of the longer work, "The Teachings of Honor"). It is this aspect of Sordello's poetry and personality that must have initially appealed to Dante and provided him with the starting point for the character of the Comedy.

The canto in which the travelers first meet Sordello, the sixth of the Purgatorio, is known as one of the three "political" cantos of the Comedy, forming a triad with the sixth cantos of the Inferno and the Paradiso (in the Inferno Dante focuses on Florence, in the Purgatorio on Italy, and in the Paradiso on the empire). Although the political aspect of Purgatorio vi comes to the fore most clearly in the invective beginning "Ahi serva Italia, di dolore ostello" (1. 76), it is signaled from the line in which Dante apostrophizes a soul, as yet unidentified, by referring to the part of Italy from which it came: "o anima lombarda ..." (1.61). This soul turns out to be Sordello, whose Lombard origins immediately draw him to Vergil. The invective against Italy derives from the ironic contrast between Sordello's loving response to Vergil as a fellow Mantuan ("e l'un l'altro abbracciava" 'and one embraced the other' [Purg. vi.75]) and the discord characteristic of Italy, where fellow citizens "gnaw" rather than embrace each other ("e l'un l'altro si rode / di quei ch'un muro e una fossa serra" 'and one gnaws at the other, of those who are enclosed by one wall and one moat' [Purg. vi.83-84]). The appellation "anima lombarda" brings to mind another episode-also politicalwhere an Italian place-name is used as a form of address; I refer to Inferno $\mathrm{x}$, where Farinata degli Uberti calls out to Dante, "O Tosco che 
per la città del foco / vivo ten vai" 'O Tuscan, who through the city of fire go alive' (1.22).

Many commentators have drawn the reader's attention to the similarities between Sordello and Farinata; Croce called Sordello the "Farinata del Purgatorio."' Both appear in episodes dealing with the theme of love of one's native land, and there are deliberate correspondences in the presentations of the two characters, correspondences that are heightened by intentional verbal echoes. Both Farinata and Sordello are isolated and haughty: "guardommi un poco, e poi, quasi sdegnoso" "he looked at me for a moment, and then, almost disdainful' (Inf. x.41; italics added here and in succeeding quotations); "come ti stavi altera e disdegnosa" "how you were haughty and disdainful' (Purg. vi.62). In each encounter Vergil sees the soul first and points it out to Dante, using the same expression: "Vedi là Farinata che s'è dritto" "See there Farinata, who has risen straight' (Inf. x.32); "Ma vedi là un'anima" 'But see there a soul' (Purg. vi.58).$^{10}$ Each time the necessary password is a sound evoking the soul's native land: Farinata hears Dante's Tuscan accent, and Sordello reacts to the first word of Vergil's reply, "Mantuia ..." (1. 72). Furthermore, in both episodes a conversation is interrupted, suspended, and suddenly resumed. Farinata and Dante are interrupted by Cavalcante de' Cavalcanti; they stop conversing until he disappears and then begin again as though he had not existed. Similarly, the conversation between Sordello and Vergil is interrupted by the apostrophe to Italy, which cuts in and continues to the end of the sixth canto. So abrupt is the break that when the conversation resumes at the beginning of the seventh canto, Sordello does not yet know who Vergil is. These devices serve rhetorically to underscore Sordello as a purgatorial corrective to Farinata. In Hell, love of one's native land is put into the context of "heresy" or divisiveness, so that Farinata is able to turn common Tuscan origins into barriers of family allegiance and party affiliation. In Purgatory, common Lombard origins become the reason for an embrace; Sordello's immediate reaction to the word "Mantuia" is part of a context that stresses unity, here the unity resulting from a shared birthplace.

Sordello, then, is related in three ways to the theme of politics in the Comedy. First, he is intrinsically connected by virtue of his historical identity as a poet concerned about the behavior of rulers in his day. Second, he is connected by his situation in the sixth, political, canto of the Purgatorio, where his embrace of Vergil, "a minute and touching demonstration of the unitive power of the political community," gives rise to the invective in which Dante deplores the lack of unity in Italy. ${ }^{11}$ Third, Sordello is the poetic refocusing of Farinata, the lens through which the theme of love of one's native land reappears on the slopes of Mount Purgatory.

The common denominator in these various aspects of the Dantesque Sordello is the concept of political unity, played against its contrary, discord and fragmentation. And here, it seems to me, there is a particular feature of Sordello's career that would have greatly interested Dante, enough to have determined Dante's development of Sordello's role. Sordello was that anomaly among poets-one who wrote in a language not his own. Although an Italian from Goito near Mantua, he wrote in Provençal. That Dante was intrigued by this is clear from what he has to say about Sordello in the De Vulgari Eloquentia: "[Sordellus] qui, tantus eloquentie vir existens, non solum in poetando, sed quomodocunque loquendo patrium vulgare deseruit."12 Dante finds it a particular sign of Sordello's "eloquentia" that Sordello should have abandoned his native tongue not just "in poetando" but in "quomodocunque loquendo," in any form of discourse whatsoever. Significantly, Dante does not cite any of Sordello's poetry in the $\mathrm{De} \mathrm{Vul}$ gari Eloquentia; all that seems to interest him is the concept of linguistic internationalism that Sordello here embodies. The De Vulgari Eloquentia is, in part, a polemic against linguistic provincialism; the "vulgare illustre" as practiced by Dante and his friend Cino da Pistoia is conceived as the Italian that would be in common use if Italy were not divided into many warring city-states but were one united nation, an Italian strained of provincial and municipal impurities. Dante singles out Sordello for praise because Sordello too reacted against the limitations of his regional dialect and, although it was not for him to discover the Italian vulgare illustre, he did the next best thing: he turned to a vulgare that was already illustre, namely Provençal.

It is well known to what extent Dante asso- 
ciated language and politics. The story of the Tower of Babel as recounted at the beginning of the De Vulgari Eloquentia shows how the fragmentation of the original language into many new ones made it impossible for the builders to work together and thus ultimately led to their political division into different peoples: “. . . ut qui omnes una eademque loquela deserviebant ad opus, ab opere multis diversificati loquelis desinerent et nunquam ad idem commertium convenirent" (Bk. I, Ch. vii, par. 6; italics mine). They came to the work with "one same language," but they left it "estranged from one another by a multiplicity of languages." In the Comedy Sordello stands for the reversal of this trend, for the initiative that would ideally lead back to the same language for all, which in turn would spell political harmony. Viewed in this context, the words with which Sordello honors Vergil in Purgatorio vii become singularly appropriate:

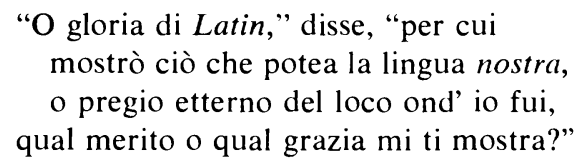

"O glory of the Latins," he said, "through whom our tongue showed what it could do, o eternal honor of the place that I was from, what merit or what grace reveals you to me?"'

(Purg. vii.16-19; italics mine)

No one has a better right than Sordello to speak of "Latins" or of "our" tongue; in his crossing of linguistic boundaries he showed himself to be a true cosmopolitan, or "Latin," aware of the common heritage that underlies all the languages of "Romania" and makes them interchangeable, "ours" as it were. It is not because he is as great a poet as Vergil that Sordello is chosen to eulogize him but because he demonstrates in his own person the unity of a linguistic tradition that is rooted in Latin language and literature and that cannot be divorced from a political tradition rooted in the Roman Empire. As there is in fact one language, shared by a Roman poet and a Lombard troubadour, so should there be one empire. And thus we come back, by a slightly different route, to Sordello as an emblem of political unity in the Comedy. Because he thought nothing of crossing both the linguistic and the political boundaries of his day, Sordello stands in opposition to the emperor, who in the invective of Canto vi is accused of not crossing boundaries: by remaining in Germany, the emperor allowed Italy to disintegrate into a swarm of warring factions and permitted the inherent unity of the Holy Roman Empire to be destroyed.

As it happens, Bertran de Born is also mentioned in the De Vulgari Eloquentia, where he appears as the prototype of the poet of arms in a Romance language, a martial poet for whom Dante can find no equivalent in Italian literature. His poetic credentials in the treatise are excellent; he is in the company of Arnaut Daniel, who represents love poetry and whose Italian counterpart is Cino da Pistoia, and Giraut de Bornelh, who as the Provençal "poet of rectitude" is paired with Dante himself. The first verse of one of Bertran's sirventes, in which he rejoices in a forthcoming battle, is quoted in full (Bk. II, Ch. ii, par. 9). Moreover, unlike Sordello, Bertran appears in the Convivio as well; he is the only poet in a group of nobles being praised for their generosity. ${ }^{13}$ Yet, in the Comedy Bertran is in the ninth bolgia of the eighth circle of Hell, among the "sowers of scandal and of schism."

Since the De Vulgari Eloquentia is a work of criticism, its evaluations of poets must meet, or at least appear to meet, certain minimal standards of impartiality and objectivity. This respect for the "truth" is waived in the Comedy, where the history of a given poet (as indeed that of any other character) is often modified according to the part that the figure has been assigned to play in the Comedy's overall scheme. As a result, Dante's treatment of a poet in the De Vulgari Eloquentia frequently differs from his treatment of the same poet in the Comedy: some figures, like Sordello, are "enlarged" in the latter work, whereas others, like Bertran, are "diminished." Still, there is always some basis in fact for Dante's distortions of history, for those aspects of an actual figure or situation that he chooses to develop out of proportion to all else.

We have seen how Dante focuses on certain aspects of the historical Sordello-his birthplace, political poetry, and language shift-to create the character of Purgatorio vi, vii, and 
viii. In his re-creation of the historical Bertran, Dante has as a starting point the amorality of Bertran's verse, as well as its sanguinary and bloodthirsty qualities, which Dante reproduces in the carnage of the ninth bolgia. But Dante's elaboration of Bertran does not rest primarily on his poetry. The key to the Dantesque character lies in the reports about Bertran that circulated in the Provençal vidas. The vidas, or biographies, exaggerate Bertran's already inflated notion of himself as Prince Henry's counselor; hence, we learn from them that Bertran was Henry's chief adviser, personally responsible for fanning the hostilities between the prince and his father. Moreover, and more important, the vidas specify that Bertran did this with his poetry:

Et era seigner, totas vez qan se volia, del rei Henric d'Englaterra e del fill de lui; mas totz temps volia qu'ill aguesson gerra ensems, lo paire $\mathrm{e} \cdot \mathrm{l}$ fills e ill fraire, l'uns ab l'autre, e totz temps volc qe $\cdot 1$ reis de Franssa $\mathrm{e} \cdot \mathrm{l}$ reis d'Englaterra agessen gerra ensems; e s'il avian patz ni treva, ades se penava $\mathrm{e} \cdot$ is percassava ab sos sirventes de desfar la patz e de mostrar cum chascuns era desonratz en la patz [italics mine].

And he was lord, whenever he wished, of King Henry of England and of his son. But he always wanted them to wage war against each other, the father and the son and the brother, the one against the other, and he always wanted the King of France and the King of England to wage war. And if they had peace or a truce, hè would put himself to great pains and strive with his sirventes to undo the peace and to show how each one was dishonored by peace. ${ }^{14}$

The sinners of the ninth bolgia are the sowers of discord; the wounds they display on their bodies correspond to the wounds that they inflicted on the social fabric during their lifetimes. Hence Bertran arrives carrying his head before him like a lantern; it is severed from his body to indicate that he severed the son from the father. His account of his sin conforms closely to the vida (there are even similar turns of phrase; compare "lo paire e $\cdot 1$ fills e ill fraire, l'uns ab l'autre" with "il padre e 'l figlio in sé”):

"E perché tu di me novella porti, sappi ch'i' son Bertram dal Bornio, quelli che diedi al re giovane i ma' conforti.
Io feci il padre e 'l figlio in sé ribelli; Achitofèl non fé più d'Absalone e di Davìd coi malvagi punzelli.

Perch'io parti' così giunte persone, partito porto il mio cerebro, lasso!, dal suo principio ch'è in questo troncone.

Così s'osserva in me lo contrapasso."

"And so that you may carry news of me, know that I am Bertran de Born, the one who gave the evil counsels to the young king. I made the father and the son into rebels against each other; Ahithophel did no more for Absalom and David with his wicked incitements. Because I disjoined persons thus united, I carry my brain, alas! disjoined from its root in this trunk. So in me the contrapasso is observed."

(Inf. xxviii.133-42)

The theme of Inferno xxviii, the sowing of discord, is fundamentally political. Bertran's sin was distinctly political; although the social unit he affected was technically the family, the family in question was a royal one, so that his actions necessarily had social and political consequences. In fact, not only Bertran's but all the sins of Inferno xxviii can be classified as social and political. Mohammed and Alì (and Fra Dolcino, who is mentioned by Mohammed) brought schism into the church; Pier da Medicina was a troublemaker in the courts of Romagna; Gaius Scribonius Curio indirectly started the civil wars by inciting Caesar to cross the Rubicon; Mosca de' Lamberti authorized the killing of Buondelmonte, thus giving rise to the Florentine factions and internecine fighting of Dante's day.

These souls are not developed as characters in any way; they are permitted only depersonalized existences under the label of "seminator di scandalo e di scisma" (1. 35). They have no significance for Dante other than as exempla of a particular sin. This is especially obvious in the depiction of Bertran de Born, as such treatment is unexpected; the De Vulgari Eloquentia and the Convivio attest to Dante's previous interest in (and respect for) Bertran both as poet and as personality. Yet here Bertran, too, is kept at a distance. He expounds the nature of his sin and its exact repercussions in Hell with mathematical clarity and precision; he presents one by one, as though filling out a dossier, his name, the sin for which he is in this 
bolgia, a biblical comparison (should the visitors need elucidation), and the correspondences between sin and punishment. ${ }^{15}$ It is no accident that he, of all the sinners in the Inferno, should be the one to enunciate the law of the contrapasso. The cold, clinical quality of his words is heightened by the pathetic interpolations "Oh me!" and "lasso!" (11. 123, 140), so at variance with the tone of the rest of his speech. In a canto where all the figures are exemplary, Bertran de Born is served up as the last and supreme exemplum: his sin is the worst, his punishment the most gruesome. ${ }^{16}$

All Dante's efforts in Inferno xxviii, in terms of the characters he presents and the way in which he presents them, are directed toward making a statement about schism, that is, toward making a political statement. This intention is reflected not only in the sins represented but in other, more subtle ways as well. The tone of the canto is set from the beginning by the fifteen-line comparison describing five battles that encompass the political history of southern Italy from Roman times to the takeover by Charles of Anjou in 1266 (11. 7-21). The reference by name to Livy, historian of Rome, is noteworthy (it is the only time in the Comedy that he is mentioned), as is the bewildering array of proper names, which has the effect of battering the reader with historical and political data. Furthermore, it is certainly significant that Inferno xxviii contains clear reminiscences of other cantos in the Inferno where Dante airs his political beliefs, namely, Inferno vi, where he discusses Florence with Ciacco, and Inferno x, where he meets the great Ghibelline leader, Farinata.

In Inferno vi Dante questions Ciacco about the whereabouts of five well-known Florentines; one of these men, Mosca de' Lamberti, turns up in Canto xxviii among the sowers of discord. There the dialogue between Dante and Mosca is reminiscent of the dialogue between Dante and Farinata in Canto $\mathrm{x}$; in both passages Dante retorts acrimoniously, saying something that causes the sinner even greater suffering. A last link between these cantos is the prophesying that occurs in all of them (politics being in some respects the art of successfully foretelling the future). In Inferno vi Ciacco hints at Dante's exile by predicting the overthrow of his party, the
Bianchi; Farinata, in Inferno $\mathrm{x}$, also alludes to Dante's exile, and then goes on to explain the nature of foresight in Hell. Therefore, it hardly seems coincidental that in Inferno xxviii "l'antiveder" 'foresight' (1. 78) is once more practiced, this time by Mohammed and Pier da Medicina. These correspondences are signposts marking the similar thematic concerns that underlie all three cantos.

As a canto that deals with a political themespecifically, the "unmaking of peace," to borrow a phrase from the Provençal vida-Inferno xxviii stands in opposition to that canto of unity and peacemaking, Purgatorio vi. Stylistic points of comparison between the two cantos support this conclusion. In his reading of Purgatorio vi, Aurelio Roncaglia has drawn attention to the recurrence of expressions denoting separation; these expressions, like "nave sanza nocchiere" 'ship without helmsman,' "sella vota" 'empty saddle,' and "vedova Roma" 'widowed Rome,' are concentrated in the invective against Italy. Roncaglia's conclusion is that "La frequenza di questa sigla avulsiva rappresenta la tormentosa fissità d'uno stato sentimentale di lacerazione" "the frequency of this rending motif represents the tormenting fixity of a sentimental state of laceration' (p. 419). Inferno xxviii also displays a motif of laceration tied to a discourse on politics; as is typical of Hell, however, the laceration is expressed, not through mere metaphors of bereavement, but through physical wounds. Hence we find, to mention only two of the bolgia's inhabitants, Alì "fesso nel volto dal mento al ciuffetto" "with his face cleft from his chin to his forelock' (1.33) and Pier da Medicina "che forata avea la gola / e tronco 'l naso infin sotto le ciglia, / e non avea mai ch'una orecchia sola" "who had his throat pierced and his nose cut off up to his eyebrows and who had only one ear' (11. 64-68). Another similarity is the massive use of proper names in both cantos, which serves to stress the historical, specific, and ephemeral nature of politics. For example, in Inferno xxviii, between lines 14 and 18, the following names occur: Ruberto Guiscardo, Ceperan, Pugliese, Tagliacozzo, and Alardo; in Purgatorio vi, in only two lines, we find Montecchi, Cappelletti, Monaldi, and Filippeschi.

Inferno xxviii, then, stands in opposition to Purgatorio vi, and in much the same way as did 
Inferno x. In the episodes of Farinata and Sordello the theme "division versus unity" is treated under the rubric, so to speak, of "love of one's native land." In the episodes of Bertran and Sordello, the same theme is treated under the rubric "poets who in their poetry fostered either divisiveness or unity." The Provençal vida specifically declares that Bertran strove to stir up trouble between father and son "ab sos sirventes" 'with his sirventes'; there is perhaps an allusion to this in Dante's verse "quelli / che diedi al re giovane i ma' conforti" 'the one who gave the evil counsels to the young king,' where the nature of the "conforti" is not specified but certainly implied. Bertran is Sordello's poetic counterpart; this is confirmed and thrown into relief by their being the only two lyric poets in the Comedy who are not love poets. Bertran's political poetry fostered disunity and schism by encouraging the Young King to disobey his father. Sordello's political poetry, by criticizing the princes in a way that prefigures Dante's own critical stance in Purgatorio vi and vii, served the final goal of political unity. Their poetry thus becomes emblematic of everything that each comes to stand for in the Comedy: one for separating, disjoining, undoing, taking apart what ought to be united; the other for crossing over, bringing together, reuniting what has been torn asunder. The relationship between the two political poets is one more strand in the web of overlapping political themes that converge in the sixth and seventh cantos of the Purgatorio and that could be diagramed as follows:

\section{Inferno vi \\ prophecy regarding
Florence $\begin{gathered}\text { Purgatorio vi and } \\ \text { vii } \\ \text { apostrophe to Italy }\end{gathered}$ \\ Inferno $\mathrm{x}$

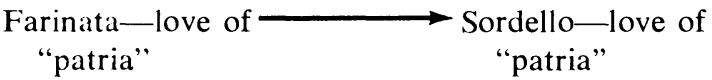 \\ $\underset{\substack{\text { Inferno xxviii } \\ \text { pertran-political }}}{\text { Sordello-political }}$ poet}

In the Comedy, therefore, Dante uses Bertran and Sordello as exempla of the uses to which a poet can put his poetry in the service of the state. For Dante, a poet does not function in a vacuum; in fact, after the stil novo phase, in which he addressed himself to a small group of initiates, Dante kept on enlarging his audience until it included, in the Comedy, anyone capable of following him. One could almost say that the larger the audience, the greater the poet. Political poets by necessity address themselves to a larger audience than do love poets; hence theirs is a greater responsibility. As one would expect, the poet in Hell, Bertran, is the exemplum of the political poet who misused his position in life. By abetting disobedience and revolt, Bertran put his poetry to bad use, mishandling the responsibility that a poet has to his audience. Sordello, in Purgatory, is the counterexemplum: the political poet who behaved responsibly and put his poetry to good use.

We can now see why Sordello is treated far more sympathetically in the Comedy than his influence or position in life would lead us to expect. The historical Sordello has been absorbed by a Sordello whose function confers on him some signal honors and privileges not granted to any other lyric poet. For instance, only the epic poets are permitted to move in the Comedy, while the lyric poets remain fixed in their respective circles, terraces, or heavens. And yet Sordello moves. Although it is true that, since he cannot leave Ante-Purgatory, he cannot move "up" in the way that Vergil and Statius do, he is nonetheless the only lyric poet to move at all. (I do not refer to movement that is part of punishment or purgation, like Guinizzelli's motion through the flames.) Sordello's presence spans three cantos, from Purgatorio vi to viii (he is mentioned for the last time in Purgatorio ix.58: "Sordel rimase e l'altre genti forme" 'Sordello remained and the other noble souls'), thus holding the stage longer than any other lyric poet. $\mathrm{He}$ greets Vergil in a manner that foreshadows Statius' greeting of Vergil later on. Most important, he serves as a guide to the travelers, even saying "a guida mi t'accosto" 'I will take your side as guide' (Purg. vii.42), thus implicitly aligning himself with the other two poet-guides, Vergil and Statius. All in all, Sordello's preeminence among the lyric poets in the Comedy is quite out of keeping with his worldly fame; one could say that he enjoys quasi-epic status.

This status is underscored by the similarity between the valley of the princes and Limbo, the 
home of the classical poets; as Bergin points out, "The garden of the princes is the 'amoenus locus' corresponding to the Limbo of the Inferno."17 Moreover, the word "onesto," etymologically related to the word "onore," which occurs eight times in various forms in Inferno iv and which is Limbo's verbal talisman, is twice used in connection with Sordello: "e nel mover de li occhi onesta e tarda" 'and in the movement of your eyes how dignified and slow' (Purg. vi.63); "Poscia che l'accoglienze oneste e liete" 'After the dignified and joyful greetings' (Purg. vii.1; my italics in both quotations). These efforts to link Sordello to the Comedy's epic and classical poets also serve to separate and distinguish him from the Comedy's lyric love poets.

By the time Dante came to write the Comedy he was incapable of an unalloyed aesthetic judgment; hence Sordello, owing to his role as a moral and political poet in the service of political unity, is given marks of distinction not accorded to other lyric poets, even though this group includes some whom we would consider poetically greater than he. For that matter, Bertran too is a greater poet than Sordello, objectively speaking, and we have seen how little this fact counts in the final judgment. Sordello's position depends entirely on the importance Dante attaches to political unity and peace as the basis, the sine qua non, of mankind's temporal wellbeing. ${ }^{18}$ Sordello's poetry does not have the educational value of epic poetry, nor does it speak to all humanity; Dante feels, however, that it comes closer to these ideals than does any other form of lyric poetry. Consequently, Dante deliberately links Sordello to the epic poets. He also takes care to make clear that, in this respect as well, Bertran is the exact opposite of Sordello. The description of Bertran in Inferno xxviii as one who carries his head like a lantern ("e 'l capo tronco tenea per le chiome, / pesol con mano a guisa di lanterna" "and it was holding the truncated head by the hair, dangling in its hand like a lantern' [11. 121-22]) and lights the way for himself by himself ("Di sé facea a sé stesso lucerna" 'Of itself it was making for itself a lamp' [1. 124]) cannot but call to mind Statius' tribute to Vergil in Purgatorio xxii: "Facesti come quei che va di notte, / che porta il lume dietro e sé non giova, / ma dopo sé fa le persone dotte" 'You did as one who goes by night, who carries the light behind him and helps not himself, but makes those who come after him wise' (11. 67-69). Bertran is a grotesque inversion of Vergil: in one there is total severance, a selfsufficiency that is not strength but meaninglessness, whereas in the other there is a sharing, a passing on, and an illumination of others even at the expense of oneself.

To end, I should like to return briefly to the world outside the Comedy. As we have seen, a comparison of the poetry of Bertran and Sordello reveals how different their attitudes are. It is interesting that Dante's treatment of these figures parallels the actual disparity; he sets them up for comparison in order to reveal them as polar opposites. In some ways, however, Dante reverses the real-life situation. Sordello, who wrote a biting and savage poem (which, had it been acted on, would have resulted in fighting in every corner of Europe), is reincarnated as an emblem of unity; whereas Bertran, whose poems in fact had little political impact, becomes an emblem of schism. The point is that both these decisions, although justifiable, are not without their arbitrary features. Dante was not interested in finding for each character in his poem a niche to correspond exactly to the merits of that person as a historical figure; he is interested in creating ideal categories that will illuminate the structure of reality as he sees it. Into these categories he fits his characters. Only in this way could his poem avoid being an inventory of dead souls and become what he wanted it to be and what it is-an insight into the nature of things so compelling that it directs the wills of the living and obliges them, through a recognition of reality, to be saved.

So it is for souls in general, and so it is for poets. If Dante has two political poets, they must perforce have more than gossip value; they must illustrate more than the fate that each found on dying. The ideal categories would naturally have to do with the use or misuse of their poetry, and Dante would look for figures whose biographies and poetic output worked well within these categories, even if not slavishly corresponding in all details. Accordingly, in his treatment of Bertran de Born and Sordello we have a clear example of Dante's deliberate revision of history for didactic purposes, to impart a moral lesson concerning the ways we use our 
gifts vis-à-vis society, and an instance of the truth of Irma Brandeis' precept that "Dante in his Comedy never serves history; he uses it . .." (p. 61). Dante's handling of the poets Bertran and Sordello thus permits us a fascinating glimpse into the workings of his own creative and poetic strategies; to put it another way, we can learn from these episodes not only something about the poetry of politics but a little about the politics of poetry as well.

\section{University of California}

Berkeley

\section{Notes}

${ }^{1}$ In "Dante and Sordello," Comparative Literature, 5 (1953), 1-15, C. M. Bowra makes a case for the importance of Sordello's long narrative poem, "Ensenhamens d'onor," noting that "each point made by Dante [in the invective of Purgatorio vi] can be paralleled by something said by Sordello [in the "Ensenhamens"]" (p. 7). Ultimately, however, Bowra gives more weight to the lament for Blacatz, thus joining all other scholars who have written on the subject. Of the older studies, the best is E. G. Parodi's "Rassegna di studi sordelliani," Bullettino della società dantesca italiana, 4 (1897), 185-97; here all the issues to be endlessly discussed by later critics are first raised. Of more recent studies, the most illuminating are Aurelio Roncaglia's "Il canto vi del Purgatorio," Rassegna della letteratura italiana, 60 (1956), 409-26, and Guido Favati's "Sordello," Cultura e scuola, 4 (1965), 551-65.

"Sordello: Le poesie, ed. Marco Boni (Bologna: Libreria Antiquaria Palmaverde, 1954), pp. 156-60. The translations from the Provençal are my own; I have attempted to make them as literal as possible.

3 Purgatorio vi.74-75; from the text established by Giorgio Petrocchi, La Commedia secondo l'antica vulgata, 4 vols. (Milan: Mondadori, 1966-67). All further quotations from the Comedy are from this edition. The translations are my own.

4 Vincenzo de Bartholomaeis, Primordi della lirica d'arte in Italia (Turin: Società Editrice Internazionale, $1943)$, p. 208.

"Thomas G. Bergin, "Dante's Provençal Gallery," Speculum, $40(1965), 15$. The idea of three troubadours in the Comedy, one for each canticle, was anticipated by E. Hoepffner in "Dante et les Troubadours," Etudes Italiennes, 4 (1922), 193-210.

${ }^{6}$ I have deliberately omitted Pier della Vigna and Forese Donati from my list of the Comedy's lyric poets. The linguistic point Dante is making about Piero is. I believe, that he is a representative of the highly rhetorical prose style of the chancellery of Frederick II, not that he is a poet of the scuola siciliana; and the episode of Forese Donati, like Dante's tenzone with Forese, tells us more about a moment in Dante's life and poetic development than it does about Forese. But even if I were to take these two figures into consideration, my observation regarding Bertran de Born and Sordello would remain unchanged. I should mention that this study, based on the idea of Bertran and Sor- dello as the two political poets among the Comedy's lyric poets, comes from my dissertation, in which I analyze Dante's treatment of all the Comedy's poets ("Dante's Poets: A Study in Poetic Revisionism" Columbia 1978).

' For the legend of Bertran de Born and the Young King, see Olin H. Moore, The Young King: Henry Plantagenet 1155-1183, in History, Literature and Tradition (Columbus: Ohio State Univ., 1925), and William D. Paden, Jr., "Bertran de Born in Italy," in Italian Literature: Roots and Branches [Essays in Honor of Thomas Goddard Bergin], ed. Giose Rimanelli and Kenneth John Atchity (New Haven: Yale Univ. Press, 1976), pp. 39-66. Although Moore suggests that Bertran may not have been so intimate with Prince Henry as the poet claims (pp. 38-47), Dante and his contemporaries certainly believed in this intimacy.

${ }^{8}$ Modern scholarship has raised the question of the authenticity of "Si tuit li dol." Carl Appel, in his edition of Bertran (Die Lieder Bertrans von Born [Halle: Max Niemeyer, 1932]), places "Si tuit li dol" among the poems of doubtful attribution, as does L. E. Kastner in "Notes on the Poems of Bertran de Born," Modern Language Review, 32 (1937), 219. For a résumé of the critical opinion on this matter, see D'Arco Silvio Avalle, ed., Peire Vidal: Poesie (Milan: Riccardo Ricciardi, 1960), ı, cxvi, n. 1. The traditional attribution of "Si tuit li dol" to Bertran is so firmly ingrained that the poem has been included in anthologies under his name even by scholars who acknowledge that the authorship is questionable; see, e.g., Anthology of the Provençal Troubadours, ed. R. T. Hill and T. G. Bergin, 2nd ed., rev. and enlarged by Thomas Bergin, with the collaboration of Susan Olson, William D. Paden, Jr., and Nathaniel Smith (New Haven: Yale Univ. Press, 1973), II, 37, and Medieval Song: An Anthology of Hymns and Lyrics, trans. and ed. James J. Wilhelm (New York: Dutton, 1971), p. 164. The only recent compiler to omit "Si tuit li dol" from a selection of Bertran's poems is Frederick Goldin, in Lyrics of the Troubadours and Trouvères (New York: Anchor-Doubleday, 1973).

9 Benedetto Croce, La poesia di Dante (Bari: Laterza, $1922)$, p. 112.

10 Giovanni Gentile points out the use of "Vedi là" in both episodes ("Il canto vi del Purgatorio" [1940]; rpt. in Letture scelte sulla Divina Commedia, ed. Gio- 
vanni Getto [Florence: Sansoni, 1970], pp. 577-93). Indeed, most of these similarities between the two cantos, with the exception of the interrupted conversation motif, which I mention below and which I have not come across elsewhere, have been previously noted in one commentary or another.

11 Irma Brandeis, The Ladder of Vision: A Study of Dante's Comedy (New York: Doubleday, 1960), p. 84.

1:De Vulgari Eloquentia, ed. Aristide Marigo, 3rd ed. (Florence: Le Monnier, 1968), Bk. I, Ch. xv, par. 2.

13 Convivio, ed. G. Busnelli and G. Vandelli, 2nd ed. (Florence: Le Monnier, 1964), Bk. IV, Ch. xi, par. 14. The source for Bertran's generosity would be the razos and perhaps two passages in the sirventes; see Moore, pp. 52, 57. It is worth noting that the only other contemporary poets mentioned in the Convivio are Giraut de Bornelh and Guido Guinizzelli; Bertran is therefore one of a very select group.

14 This passage is from the first of the two biographies of Bertran de Born. The text is from Le biografie trovadoriche, ed. Guido Favati (Bologna: Libreria Antiquaria Palmaverde, 1961), p. 147. The case for Dante's knowledge both of Bertran's poetry and of the Provençal biographies is stated by Moore, pp. 74-78.

15 Bertran compares himself to Ahithophel, a counselor who urged Absalom to rebel against his father, King David. Interestingly, Dante is not the first to suggest a parallel between these biblical figures and the Young King and his father. William of Newburgh reports that when Prince Henry escaped to his fatherin-law, Louis vil of France, in 1173, Henry II sent a committee to Louis demanding the return of his "Absalom" (see Moore, p. 10).

16 On a textual level as well, the entire canto is a preparation for its pièce de résistance, Bertran de Born.
There are echoes of Bertran's poetry throughout Inferno xxviii, starting with the imitation of the opening of "Si tuit li dol" in 11. 7-21. (See the commentary on the Inferno in The Divine Comedy, trans., with commentary, Charles S. Singleton [Princeton: Princeton Univ. Press, 1970-75], pp. 496, 502, 506.)

For the distancing rhetoric of this canto, which deliberately depersonalizes the sinners, see the excellent study by Mario Fubini, "Il canto xxviII dell' Inferno," Lectura Dantis Scaligera (Florence: Le Monnier, 1967), pp. 999-1021.

Regarding the criticism of this canto, the classic studies are Michele Scherillo's "Bertram dal Bornio e il Re Giovane," Nuova antologia, 154 (1897), 452-78; and Vincenzo Crescini's "Il canto XxviII dell'Inferno," Lectura Dantis (Florence: Sansoni, 1907); rpt. in Letture scelte sulla Divina Commedia, ed. Giovanni Getto (Florence: Sansoni, 1970), pp. 383-98. An interesting recent article is Marianne Shapiro's "The Fictionalization of Bertran de Born," Dante Studies, 92 (1974), 107-16, which deals with the episode as a moment in the Comedy's "askesis of the entire troubadour tradition" (p. 109).

17 "Dante's Provençal Gallery," p. 29; for the similarities of the valley to Limbo, also see Parodi, p. 193. In showing that Sordello is "one of the important and impressive figures in the Purgatory," Bergin points out that "his presence takes in three cantos" and that "he is a true guide" (p. 25).

18 See the Monarchia, ed. Pier Giorgio Ricci (Verona: Mondadori, 1965), Bk. I, Ch. iv, par. 2: "Unde manifestum est quod pax universalis est optimum eorum que ad nostram beatitudinem ordinantur" "Thus it is shown that universal peace is the best of those things that are regulated for our happiness' (translation mine). 